\title{
Ferrocene-Based Bioactive Bimetallic Thiourea Complexes: Synthesis and Spectroscopic Studies
}

\author{
Shafqat Ali, ${ }^{1,2}$ Ghulam Yasin, ${ }^{1}$ Zareen Zuhra, ${ }^{1}$ Zhanpeng Wu, ${ }^{1}$ Ian S. Butler, ${ }^{2}$ \\ Amin Badshah, ${ }^{3}$ and Imtiaz ud Din $^{3}$ \\ ${ }^{1}$ Key Laboratory of Carbon Fiber and Functional Polymers, Beijing University of Chemical Technology Ministry of Education, \\ Beijing 100029, China \\ ${ }^{2}$ Department of Chemistry, McGill University, Montreal, QC, Canada H3A 2 K6 \\ ${ }^{3}$ Department of Chemistry, Quaid-i-Azam University, Islamabad 45320, Pakistan
}

Correspondence should be addressed to Zhanpeng Wu; drzhanpengwu.buct@gmail.com

Received 29 July 2015; Revised 17 September 2015; Accepted 17 September 2015

Academic Editor: Zhe-Sheng Chen

Copyright (C) 2015 Shafqat Ali et al. This is an open access article distributed under the Creative Commons Attribution License, which permits unrestricted use, distribution, and reproduction in any medium, provided the original work is properly cited.

Bioactive $1,1^{\prime}-\left(4,4^{\prime}\right.$-di-ferrocenyl)di-phenyl thiourea and various metal complexes of this ligand have been successfully synthesized and characterized by using physicoanalytical techniques such as FT-IR and multinuclear $\left({ }^{1} \mathrm{H}\right.$ and $\left.{ }^{13} \mathrm{C}\right)$ NMR spectroscopy along with melting point and elemental analyses. The interaction of the synthesized compounds with DNA has been investigated by using cyclic voltammetric and viscometric measurements. The intercalation of the complexes into the double helix structure of DNA is presumably occurring. Viscosity measurements of the complexes have shown that there is a change in length and this is regarded as the least ambiguous and the most critical test of the binding model in solution. The relative potential of the complexes as anti-bacterial, antifungal, and inhibition agents against the enzyme, alkaline phosphatase EC 3.1.3.1, has also been assessed and the complexes were found to be active inhibitors.

\section{Introduction}

One of the essential goals in medical community is to introduce the new anticancer and antimicrobial therapeutic agents. Cancer treatment using metal-based drugs is one of the very effective strategies; for example, platinum drugs cisplatin, carboplatin, and oxaliplatin are routinely used in the clinic to kill cancerous cells but their use has also been limited due to inherent and acquired resistance and the presence of a number of dose-limiting side effects $[1,2]$. The search for better metal-based drugs having the ability to overcome problems of drug resistance and side effects associated with platinum based chemotherapy constitutes the foundation of bioorganometallic chemistry. Ferrocene and its derivatives have played an important role as potential chemotherapeutics in particular; considerable attention has been paid to their antitumour, anti-inflammatory, antimicrobial, cytotoxic, and DNA cleaving agents with respect to cancer cells [1-4]. The stability, electroactivity, and high spectroscopic activity of ferrocene-based organometallics make them promising candidates for many biological applications [5]. The presence of the ferrocenyl moiety enhances activity due to its reversible redox behaviour and increases cell permeability due to its lipophilic nature [6]. It has been reported that when ferrocene was incorporated into tamoxifen, the anticancer activity of the drug is enhanced [7]. Ferrocene derivatives may bind to the DNA via both covalent and noncovalent modes of interaction. The anticancer activity of ferrocene derivatives is found to be dependent on the oxidation state of iron in the ferrocene moiety with some results indicating that the Fe(II) ferrocenyl compound is more active than $\mathrm{Fe}(\mathrm{III})$ ones [8]. The results of the study on ferrocifen as one of the $\mathrm{Fe}(\mathrm{II})$ compounds indicate that the ferrocifens act by changing the conformation of the receptor protein [9]. Binding of ferrocifen to ER $\beta$ is thought to lead to its dimerization followed by attachment of the dimerized species to a particular region of DNA. The electron transfer reaction involving the ferrocenium ion in vivo or the ferrocifen-ER $\beta$ complex may generate reactive oxygen 
species (ROS) such as hydroxyl radicals $\left({ }^{\circ} \mathrm{OH}\right)$. ROS produced can cause damage to DNA [10] and may also be responsible for anticancer activity through the formation of radical metabolites that bring about biological damage in the cancer cell $[11,12]$.

Many researchers have reported that thiourea-based complexes show effective results against various biological activities due to the presence of thiocarbonyl moiety which affect biochemical action by the lipophilicity/hydrophilicity and electronic properties of the compounds [13-16]. Herein we report the synthesis, characterization, and investigation of DNA interaction, enzymatic studies, and antibacterial and antifungal activities of various metal complexes of ferrocenebased thiourea and we believe that this study will provide useful information on various biological domains and thus will be very helpful to the design of new drug.

\section{Materials and Methods}

2.1. Chemicals and Instrumentation. Ferrocene, hydrochloric acid, sodium nitrite, acetonitrile, dimethyl sulfoxide (DMSO), ethanol, diethyl ether, carbon disulfide, triethylamine, metal salts (Pd, Ag, Cd, $\mathrm{Zn}, \mathrm{Hg}$, etc.), ammonium formate, zinc-dust, and alkaline phosphatase (ALP, EC 3.1.3.1) were obtained from E. Merck and Aldrich (Pakistan). All solvents were dried and purified before use according to the reported methods [18]. Elemental analyses (CHNS) were performed using an in-house instrument, Leco CHNS-932 Elemental Analyzer. Melting points were measured using a BIO COTE Model SMP10 melting point apparatus. The FT-IR spectra $(4,000-400) \mathrm{cm}^{-1}$ were obtained using $\mathrm{KBr}$ disks on a Thermo Scientific Nicolet-6700 FT-IR spectrometer. The NMR spectra of the complexes were recorded using a Bruker Avance $300 \mathrm{MHz}$ NMR spectrometer.

2.2. Synthesis of $1,1^{\prime}-\left(4,4^{\prime}\right.$-Di-ferrocenyl $)$ di-phenyl Thiourea (Ft). 3-Ferrocenylaniline was synthesized in accordance with the methodology reported earlier [17]. An ethanolic solution of 3 -ferrocenylaniline $(2.0 \mathrm{mmol})$ was added dropwise to a solution of carbon disulfide $(1.0 \mathrm{mmol})$ containing a few drops of triethylamine in an ice bath $\left(0-5^{\circ} \mathrm{C}\right)$ and then reaction mixture was stirred overnight at room temperature. The progress of the reaction was monitored by TLC. After completion, the reaction mixture was filtered off and the residue was recrystallized from acetonitrile to obtain the symmetrical ferrocene-based thiourea ligand (Ft); Yield $65 \%$, m.p., $180^{\circ} \mathrm{C}$. Molecular formula (Mol. wt.) is found as $\mathrm{C}_{33} \mathrm{H}_{24} \mathrm{Fe}_{2} \mathrm{~N}_{2} \mathrm{~S}$ (596). FT-IR $\left(\nu, \mathrm{cm}^{-1}\right)$ : Fe-Cp $\left(490 \mathrm{~cm}^{-1}\right), \mathrm{NH}$ $\left(3354 \mathrm{~cm}^{-1}\right), \mathrm{sp}^{2} \mathrm{CH}\left(3084 \mathrm{~cm}^{-1}\right), \mathrm{C}=\mathrm{C} \mathrm{Ar}\left(1587 \mathrm{~cm}^{-1}\right)$, metadisubstituted benzene $\left(883 \mathrm{~cm}^{-1}\right), \mathrm{C}=\mathrm{S}\left(740 \mathrm{~cm}^{-1}\right) .{ }^{1} \mathrm{H}$ NMR $\left(300 \mathrm{MHz}, \mathrm{CDCl}_{3}\right.$ ): $\delta 4.09\left(\mathrm{~s}, 5 \mathrm{H}, \mathrm{C}_{5} \mathrm{H}_{5}\right.$ ), $4.36\left(\mathrm{~s}, 2 \mathrm{H}, \mathrm{C}_{5} \mathrm{H}_{4}\right.$ ), $4.66\left(\mathrm{~s}, 2 \mathrm{H}, \mathrm{C}_{5} \mathrm{H}_{4}\right), 7.59\left(\mathrm{~s}, 1 \mathrm{H}, \mathrm{C}_{6} \mathrm{H}_{4}\right), 7.22(\mathrm{~d}, 1 \mathrm{H}, J=7.8 \mathrm{~Hz}$, $\left.\mathrm{C}_{6} \mathrm{H}_{4}\right), 7.42\left(\mathrm{t}, 1 \mathrm{H}, J=7.8 \mathrm{~Hz}, \mathrm{C}_{6} \mathrm{H}_{4}\right), 7.34(\mathrm{t}, 1 \mathrm{H}, J=7.8 \mathrm{~Hz}$, $\left.\mathrm{C}_{6} \mathrm{H}_{4}\right), 7.99$ (s, $\left.1 \mathrm{H}, \mathrm{NH}\right)$ ppm.

${ }^{13} \mathrm{C}$ NMR $\left(75 \mathrm{MHz} \mathrm{CDCl}_{3}\right): \delta 69.75,69.35,66.67,83.99$, $137.15,122.78,141.54,124.72,129.53,122.33$, 179.77 ppm. Elemental analysis Cal.(\%): C, 66.46; H, 4.73; N, 4.70; S, 5.38. Found (\%): C, 66.39; H, 4.74; N, 4.68; S, 5.34.
2.3. Synthesis of Metal Complexes. The target compounds (15) were synthesized by the following general procedure.

An acetonitrile solution of ferrocene-based thiourea (Ft) was added dropwise to an acetonitrile solution of the appropriate metal salt $(\mathrm{Zn}, \mathrm{Cd}, \mathrm{Hg}, \mathrm{Pd}$, and $\mathrm{Ag}$ ) in a $1: 2$ mole ratio and the reaction mixture was stirred for $4-6 \mathrm{~h}$ at room temperature; the extent of the reaction was monitored by TLC. After completion of the reaction, the mixture was filtered off and the residue was isolated. This solid material was dissolved in dichloromethane and then recrystallized using $n$-hexane: chloromethane mixture $(1: 3)$. Unfortunately, the crystals obtained were not of sufficient quality for singlecrystal X-ray diffraction analysis.

2.4. FT-IR and Multinuclear $\left({ }^{1} \mathrm{H}\right.$ and $\left.{ }^{13} \mathrm{C}\right)$ NMR Studies. The FT-IR and multinuclear $\left({ }^{1} \mathrm{H}\right.$ and $\left.{ }^{13} \mathrm{C}\right)$ NMR spectral data for the complexes are as follows.

For compound 1 with molecular formula (Mol. wt.) found as $\mathrm{C}_{66} \mathrm{H}_{56} \mathrm{Cl}_{2} \mathrm{Fe}_{4} \mathrm{~N}_{4} \mathrm{~S}_{2} \mathrm{Zn}$ (1328), FT-IR ( $\left.\nu, \mathrm{cm}^{-1}\right)$ : Fe$\mathrm{Cp}\left(486 \mathrm{~cm}^{-1}\right), \mathrm{NH}\left(3204 \mathrm{~cm}^{-1}\right), \mathrm{sp}^{2} \mathrm{CH}\left(2962 \mathrm{~cm}^{-1}\right), \mathrm{C}=\mathrm{C}$ $\operatorname{Ar}\left(1525 \mathrm{~cm}^{-1}\right)$, meta-disubstituted benzene $\left(880 \mathrm{~cm}^{-1}\right), \mathrm{C}=\mathrm{S}$ $\left(724 \mathrm{~cm}^{-1}\right) .{ }^{1} \mathrm{H}$ NMR $(300 \mathrm{MHz}, \mathrm{DMSO}): \delta 4.06(\mathrm{~s}, 10 \mathrm{H}$, $\left.\mathrm{C}_{5} \mathrm{H}_{5}\right), 4.34\left(\mathrm{~s}, 4 \mathrm{H}, \mathrm{C}_{5} \mathrm{H}_{4}\right), 4.73\left(\mathrm{~s}, 4 \mathrm{H}, \mathrm{C}_{5} \mathrm{H}_{4}\right), 7.71(\mathrm{~s}, 2 \mathrm{H}$, $\left.\mathrm{C}_{6} \mathrm{H}_{4}\right), 7.27\left(\mathrm{~d}, 2 \mathrm{H}, J=7.5 \mathrm{~Hz}, \mathrm{C}_{6} \mathrm{H}_{4}\right), 7.33(\mathrm{t}, 2 \mathrm{H}, J=$ $\left.7.5 \mathrm{~Hz}, \mathrm{C}_{6} \mathrm{H}_{4}\right), 7.36\left(\mathrm{~d}, 2 \mathrm{H}, J=7.5 \mathrm{~Hz}, \mathrm{C}_{6} \mathrm{H}_{4}\right), 9.81(\mathrm{~s}, 2 \mathrm{H}$, $\mathrm{NH})$ ppm. ${ }^{13} \mathrm{C}$ NMR (75 MHz, DMSO): $\delta 69.85,69.35,66.56$, 85.18, 139.85, 121.94, 139.88, 122.70, 128.82, 121.73, 177.18 ppm. Elemental analysis Cal.(\%): C, 59.65; H, 4.25; N, 4.22; S, 4.83; Found (\%): C, 59.71; H, 4.21; N, 4.19; S, 4.83. Yield 45\% and m.p., $240^{\circ} \mathrm{C}$.

For compound 2 with molecular formula (Mol. wt.) $\mathrm{C}_{66} \mathrm{H}_{56} \mathrm{Cl}_{2} \mathrm{Fe}_{4} \mathrm{~N}_{4} \mathrm{~S}_{2} \mathrm{Cd}$ (1376), FT-IR $\left(\nu, \mathrm{cm}^{-1}\right)$ : Fe-Cp $\left(484 \mathrm{~cm}^{-1}\right), \mathrm{NH}\left(3290 \mathrm{~cm}^{-1}\right), \mathrm{sp}^{2} \mathrm{CH}\left(3097 \mathrm{~cm}^{-1}\right), \mathrm{C}=\mathrm{C} \mathrm{Ar}$ $\left(1590 \mathrm{~cm}^{-1}\right)$, meta-disubstituted benzene $\left(885 \mathrm{~cm}^{-1}\right), \mathrm{C}=\mathrm{S}$ $\left(728 \mathrm{~cm}^{-1}\right) .{ }^{1} \mathrm{H}$ NMR $(300 \mathrm{MHz}, \mathrm{DMSO}): \delta 4.09(\mathrm{~s}, 10 \mathrm{H}$, $\left.\mathrm{C}_{5} \mathrm{H}_{5}\right), 4.35\left(\mathrm{~s}, 4 \mathrm{H}, \mathrm{C}_{5} \mathrm{H}_{4}\right), 4.66\left(\mathrm{~s}, 4 \mathrm{H}, \mathrm{C}_{5} \mathrm{H}_{4}\right), 7.60(\mathrm{~s}, 2 \mathrm{H}$, $\left.\mathrm{C}_{6} \mathrm{H}_{4}\right), 7.22\left(\mathrm{~d}, 2 \mathrm{H}, J=7.5 \mathrm{~Hz}, \mathrm{C}_{6} \mathrm{H}_{4}\right), 7.34(\mathrm{t}, 2 \mathrm{H}, J=7.8 \mathrm{~Hz}$, $\left.\mathrm{C}_{6} \mathrm{H}_{4}\right), 7.41\left(\mathrm{~d}, 2 \mathrm{H}, J=7.5 \mathrm{~Hz}, \mathrm{C}_{6} \mathrm{H}_{4}\right), 10.08(\mathrm{~s}, 2 \mathrm{H}, \mathrm{NH}) \mathrm{ppm}$. ${ }^{13} \mathrm{C}$ NMR (75 MHz, DMSO): $\delta$ 69.85, 68.50, 65.75, 83.05, $136.20,121.72,140.51,121.26,128.59,123.65,175.56 \mathrm{ppm}$. Elemental analysis Cal.(\%): C, 57.61; H, 4.10; N, 4.07; S, 4.66; Found (\%): C, 57.44; H, 4.14; N, 4.04; S, 4.65. Yield 60\% and m.p., $230^{\circ} \mathrm{C}$.

For compound 3 with molecular formula (Mol. wt.) calculated as $\mathrm{C}_{68} \mathrm{H}_{56} \mathrm{Cl}_{2} \mathrm{Fe}_{4} \mathrm{HgN}_{6} \mathrm{~S}_{2}$ (1464), FT-IR ( $\left.\nu, \mathrm{cm}^{-1}\right)$ : Fe$\mathrm{Cp}\left(490 \mathrm{~cm}^{-1}\right), \mathrm{NH}\left(3091 \mathrm{~cm}^{-1}\right), \mathrm{sp}^{2} \mathrm{CH}\left(2928 \mathrm{~cm}^{-1}\right), \mathrm{C}=\mathrm{C}$ $\operatorname{Ar}\left(1576 \mathrm{~cm}^{-1}\right)$, meta-disubstituted benzene $\left(893 \mathrm{~cm}^{-1}\right), \mathrm{CN}$ $\left(2353 \mathrm{~cm}^{-1}\right), \mathrm{C}=\mathrm{S}\left(631 \mathrm{~cm}^{-1}\right) .{ }^{1} \mathrm{H}$ NMR $(300 \mathrm{MHz}, \mathrm{DMSO}): \delta$ $4.22\left(\mathrm{~s}, 10 \mathrm{H}, \mathrm{C}_{5} \mathrm{H}_{5}\right), 4.29\left(\mathrm{~s}, 4 \mathrm{H}, \mathrm{C}_{5} \mathrm{H}_{4}\right), 4.62\left(\mathrm{~s}, 4 \mathrm{H}, \mathrm{C}_{5} \mathrm{H}_{4}\right)$, $6.77\left(\mathrm{~s}, 2 \mathrm{H}, \mathrm{C}_{6} \mathrm{H}_{4}\right), 6.44\left(\mathrm{~d}, 2 \mathrm{H}, J=7.2 \mathrm{~Hz}, \mathrm{C}_{6} \mathrm{H}_{4}\right), 7.11(\mathrm{t}$, $\left.2 \mathrm{H}, J=7.8 \mathrm{~Hz}, \mathrm{C}_{6} \mathrm{H}_{4}\right), 7.21\left(\mathrm{~d}, 2 \mathrm{H}, J=7.5 \mathrm{~Hz}, \mathrm{C}_{6} \mathrm{H}_{4}\right), 10.16$ (s, $2 \mathrm{H}, \mathrm{NH}) \mathrm{ppm} .{ }^{13} \mathrm{C} \mathrm{NMR}(75 \mathrm{MHz}, \mathrm{DMSO}): \delta 68.85,68.60$, 65.85, 83.15, 136.31, 121.85, 140.62, 121.39, 128.60, 123.76, 176.65, 144.62 ppm. Elemental analysis Cal.(\%): C, 54.14; H, 3.86; N, 5.83; S, 4.38; Found (\%): C, 54.11; H, 3.89; N, 5.83; S, 4.42. Yield $70 \%$ and m.p., $240^{\circ} \mathrm{C}$.

For compound 4 with molecular formula (Mol. wt.) found as $\mathrm{C}_{66} \mathrm{H}_{56} \mathrm{Cl}_{2} \mathrm{Fe}_{4} \mathrm{~N}_{4} \mathrm{PdS}_{2}$ (1370), FT-IR ( $\left.\nu, \mathrm{cm}^{-1}\right)$ : Fe-Cp 
$\left(483 \mathrm{~cm}^{-1}\right), \mathrm{NH}\left(3200 \mathrm{~cm}^{-1}\right), \mathrm{sp}^{2} \mathrm{CH}\left(3090 \mathrm{~cm}^{-1}\right), \mathrm{C}=\mathrm{C} \mathrm{Ar}$ $\left(1584 \mathrm{~cm}^{-1}\right)$, meta-disubstituted benzene $\left(878 \mathrm{~cm}^{-1}\right), \mathrm{C}=\mathrm{S}$ $\left(734 \mathrm{~cm}^{-1}\right) .{ }^{1} \mathrm{H}$ NMR $(300 \mathrm{MHz}, \mathrm{DMSO}): \delta 4.06(\mathrm{~s}, 10 \mathrm{H}$, $\left.\mathrm{C}_{5} \mathrm{H}_{5}\right), 4.35\left(\mathrm{~s}, 4 \mathrm{H}, \mathrm{C}_{5} \mathrm{H}_{4}\right), 4.73\left(\mathrm{~s}, 4 \mathrm{H}, \mathrm{C}_{5} \mathrm{H}_{4}\right), 7.71(\mathrm{~s}, 2 \mathrm{H}$, $\left.\mathrm{C}_{6} \mathrm{H}_{4}\right), 7.25\left(\mathrm{~d}, 2 \mathrm{H}, J=7.8 \mathrm{~Hz}, \mathrm{C}_{6} \mathrm{H}_{4}\right), 7.32(\mathrm{t}, 2 \mathrm{H}, J=$ $\left.6.9 \mathrm{~Hz}, \mathrm{C}_{6} \mathrm{H}_{4}\right), 7.39\left(\mathrm{~d}, 2 \mathrm{H}, J=6.9 \mathrm{~Hz}, \mathrm{C}_{6} \mathrm{H}_{4}\right), 9.81(\mathrm{~s}, 2 \mathrm{H}$, $\mathrm{NH}) \mathrm{ppm} .{ }^{13} \mathrm{CNMR}(75 \mathrm{MHz}, \mathrm{DMSO}): \delta 68.75,68.50,65.75$, $83.05,136.21,121.75,140.52,121.29,128.50,123.66,171.45 \mathrm{ppm}$. Elemental analysis Cal.(\%): C, 57.86; H, 4.12; N, 4.09; S, 4.68; Found (\%): C, 57.83; H, 4.15; N, 4.07; S, 4.69. Yield 60\% and m.p., $210^{\circ} \mathrm{C}$.

For compound 5 with molecular formula (Mol. wt.) $\mathrm{C}_{66} \mathrm{H}_{56} \mathrm{Fe}_{4} \mathrm{~N}_{5} \mathrm{O}_{3} \mathrm{~S}_{2} \mathrm{Ag} \quad(1361)$, FT-IR $\left(\nu, \mathrm{cm}^{-1}\right)$ : $\quad \mathrm{Fe}-\mathrm{Cp}$ $\left(483 \mathrm{~cm}^{-1}\right), \mathrm{NH}\left(3290 \mathrm{~cm}^{-1}\right), \mathrm{sp}^{2} \mathrm{CH}\left(3083 \mathrm{~cm}^{-1}\right), \mathrm{C}=\mathrm{C} \mathrm{Ar}$ $\left(1583 \mathrm{~cm}^{-1}\right)$, meta-disubstituted benzene $\left(881 \mathrm{~cm}^{-1}\right)$, NOasym $\left(1580 \mathrm{~cm}^{-1}\right)$, NO-sym $\left(1541 \mathrm{~cm}^{-1}\right), \mathrm{C}=\mathrm{S}\left(724 \mathrm{~cm}^{-1}\right) .{ }^{1} \mathrm{H}$ NMR (300 MHz, DMSO): $\delta 4.03\left(\mathrm{~s}, 10 \mathrm{H}, \mathrm{C}_{5} \mathrm{H}_{5}\right), 4.36(\mathrm{~s}, 4 \mathrm{H}$, $\left.\mathrm{C}_{5} \mathrm{H}_{4}\right), 4.77\left(\mathrm{~s}, 4 \mathrm{H}, \mathrm{C}_{5} \mathrm{H}_{4}\right), 7.49\left(\mathrm{~s}, 2 \mathrm{H}, \mathrm{C}_{6} \mathrm{H}_{4}\right), 7.16(\mathrm{~d}, 2 \mathrm{H}$, $\left.J=6.9 \mathrm{~Hz}, \mathrm{C}_{6} \mathrm{H}_{4}\right), 7.34\left(\mathrm{t}, 2 \mathrm{H}, J=7.5 \mathrm{~Hz}, \mathrm{C}_{6} \mathrm{H}_{4}\right), 7.42(\mathrm{~d}, 2 \mathrm{H}$, $\left.J=7.5 \mathrm{~Hz}, \mathrm{C}_{6} \mathrm{H}_{4}\right), 10.22(\mathrm{~s}, 2 \mathrm{H}, \mathrm{NH}) \mathrm{ppm} .{ }^{13} \mathrm{CNMR}(75 \mathrm{MHz}$, DMSO): $\delta 69.89,69.28,66.91,84.73,138.98,123.82,140.44$, $122.7,129.53,116.38,172.43 \mathrm{ppm}$. Elemental analysis Cal.(\%): C, 58.18; H, 4.11; N, 5.14; S, 4.71; Found (\%): C, 58.19; H, $4.13 ; \mathrm{N}, 5.19 ; \mathrm{S}, 4.74$. Yield $50 \%$ and m.p., $230^{\circ} \mathrm{C}$.

2.5. DNA Binding Studies by Cyclic Voltammetry and Viscometry. Cyclic voltammetric (CV) measurements were performed in a single compartment cell with a three-electrode configuration using an Eco Chemie Auto lab PGSTAT 12 potentiostat/galvanostat (Utrecht, The Netherlands) instrument equipped with the electrochemical software package GPES 4.9. The three-electrode system consisted of reference electrode: $\mathrm{RE}-1 \mathrm{~B}$ silver-silver chloride $(\mathrm{Ag} / \mathrm{AgCl})$ saturated with sodium chloride $(\mathrm{NaCl})$ of length $70 \mathrm{~mm}$ and outer diameter of $6.0 \mathrm{~mm}$ (ALS category number 012167), a Beckman platinum wire of thickness $0.5 \mathrm{~mm}$ with an exposed end of $10 \mathrm{~mm}$ as the counter electrode, and a bare glassy carbon electrode (surface area of $0.071 \mathrm{~cm}^{2}$ ) as working electrode. The voltammogram of a known volume of the test solution was recorded in the absence of calf thymus DNA (CT-DNA) after flushing out oxygen by purging with argon gas for 10 min just prior to each experiment. The procedure was then repeated for systems with constant concentration of the compounds Ft and 1-5 (1 mM) and increasing concentration of CT-DNA $(1 \mathrm{~mL}$ of $20,40 \mu \mathrm{M})$. All the sample solutions were prepared in $20 \%$ aqueous DMSO and buffered at $\mathrm{pH} 7$ by phosphate buffer $\left(0.1 \mathrm{M} \mathrm{NaH}_{2} \mathrm{PO}_{4}+0.1 \mathrm{M} \mathrm{NaOH}\right) ; 0.1 \mathrm{mM}$ potassium chloride $(\mathrm{KCl})$ was used as supporting electrolyte. The working electrode was cleaned after every electrochemical assay [19]. The stock solution of CT-DNA $(200 \mu \mathrm{M})$ was prepared by using doubly distilled water and stored at $4^{\circ} \mathrm{C}$. The concentration of CT-DNA was determined by UV absorbance at $260 \mathrm{~nm}$ (molar coefficient $\epsilon$ of CT-DNA was taken as $\left.6600 \mathrm{M}^{-1} \mathrm{~cm}^{-1}\right)$. The nucleotide to protein (N/P) ratio of 1.85 was obtained from the ratio of absorbance at 260 and $280 \mathrm{~nm}(\mathrm{~A} 260 / \mathrm{A} 280=1.85)$, providing evidence for protein-free DNA [20].
Viscosity measurements were carried out using Oswald Viscometer, maintained at a constant temperature at $25.0 \pm$ $0.1^{\circ} \mathrm{C}$ in a thermostatic bath. A series of solutions were made with varying concentration of DNA and constant concentration of the compound. Flow times were measured with a digital stopwatch, and each solution of the complexes was measured three times, and an average flow time was calculated. Data are presented as $\eta / \eta_{0}$ versus binding ratio [compound]/[DNA], where $\eta$ is the viscosity of DNA in the presence of complex and $\eta_{0}$ is the viscosity of DNA alone. All the experiments were conducted in $0.1 \mathrm{M}$ phosphate buffer $(\mathrm{pH} 7)$ at $25^{\circ} \mathrm{C}$ and the results were the average of three experimental measurements.

2.6. Enzyme Inhibition Studies. The basic principle of this study is that the alkaline phosphatase in the sample catalyzes the hydrolysis of colorless p-nitrophenyl phosphate (p-NPP) to give $\mathrm{p}$-nitrophenol and inorganic phosphate. At the $\mathrm{pH}$ of the assay (alkaline), the p-nitrophenol is in the yellow phenoxide form. The rate of absorbance increase at $405 \mathrm{~nm}$ is directly proportional to the alkaline phosphatase activity in the sample. Synthesized compounds Ft and $\mathbf{1 - 5}$ were screened for their inhibitory activity against the enzyme alkaline phosphatase, EC 3.1.3.1. The enzyme activity was monitored spectrophotometrically at constant temperature $\left(25^{\circ} \mathrm{C}\right)$ through the increase in absorbance at $405 \mathrm{~nm}$, which is associated with the hydrolysis of the substrate, para-nitrophenyl phosphate (pNPP). The reaction was started by addition of $40 \mu \mathrm{L}$ of the enzyme to $2 \mathrm{~mL}$ of an assay system in DMSO containing $2 \mathrm{mM}$ pNPP in $0.05 \mathrm{M} \mathrm{Na}_{2} \mathrm{CO}_{3}-\mathrm{NaHCO}_{3}$ buffer ( $\mathrm{pH} \mathrm{10.0)}$ at different concentrations of the complexes. Absorption measurements were recorded using a Beckman U-2020 spectrophotometer.

2.7. Antibacterial Assay. The successful locally isolated pathogens from (1) urinary tract infections (indigenous uropathogens), that is, Klebsiella pneumonia and Escherichia coli, and (2) other hospital acquired infections, that is, Staphylococcus aureus and Micrococcus luteus, were examined for antibacterial activities. All synthesized compounds were tested by a reported method with minor modifications (agar well diffusion assay) $[17,21]$ where imipenem was used as the standard antibiotic [22]. The whole experiment was performed at $\mathrm{pH}$ 7, using appropriate concentration of reagents and McFarland solution as turbidity standard. Using a micropipette, $30 \mu \mathrm{L}$ of each compound was poured in their respective wells. The incubated time was $24 \mathrm{~h}$ at $37^{\circ} \mathrm{C}$. The zone of inhibition (\%) was calculated for each compound and compared with the standard antibiotic.

2.8. Antifungal Assay. Antifungal screening of the synthesized compounds (Ft and 1-5) was carried out against Aspergillus niger. Terbinafine was used as standard drug [23]. Different concentrations of each compound $(3 \mathrm{mg} / \mathrm{mL}, 5 \mathrm{mg} /$ $\mathrm{mL}$, and $20 \mathrm{mg} / \mathrm{mL}$ ) were prepared in $100 \mathrm{~mL}$ of DMSO. Tubes were loaded with solutions of each compound, standard drug (negative), and positive control (DMSO) in the growth medium by using a micropipette. Fungal spores were transferred to each growth culture test tube during assay 


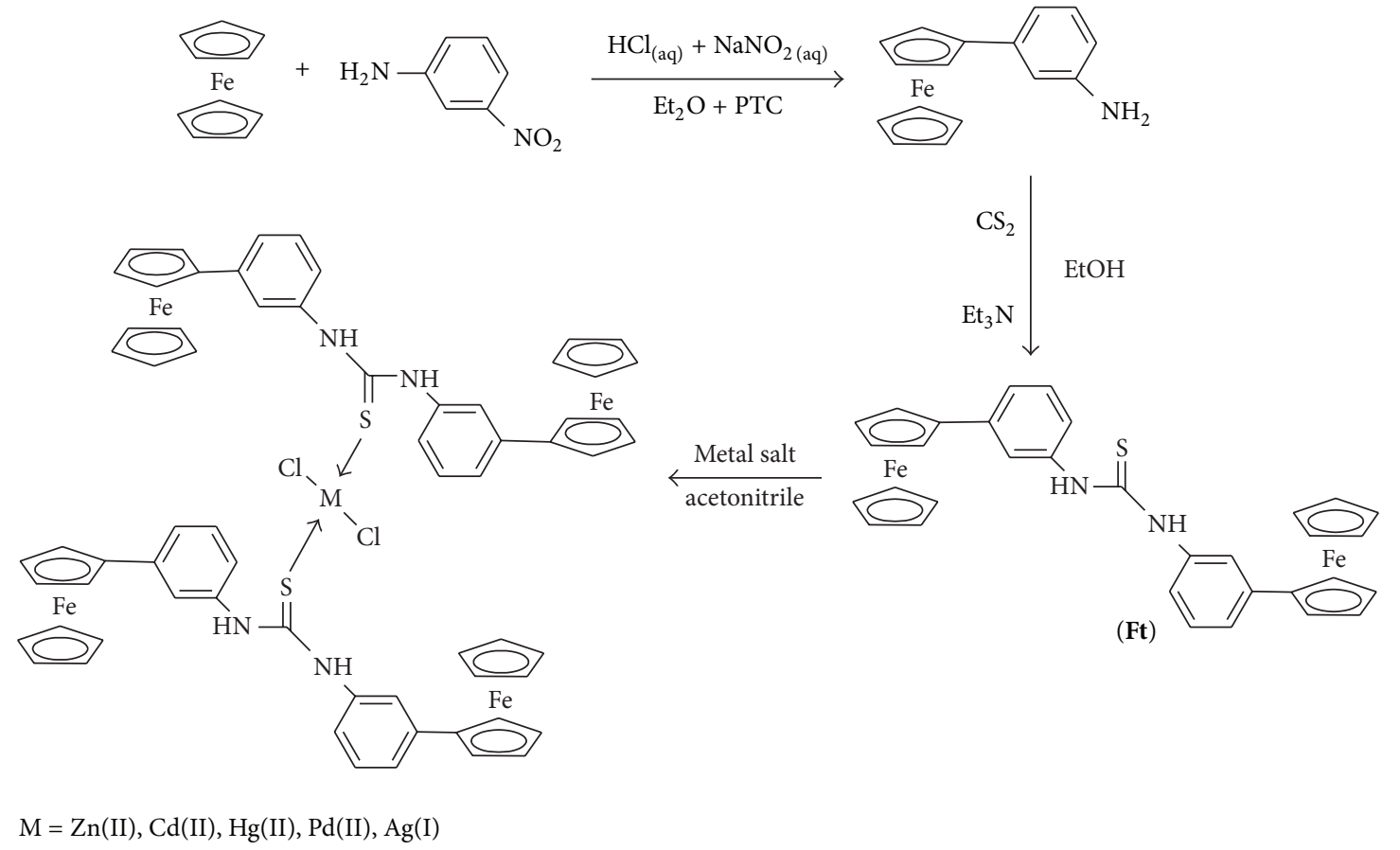

Scheme 1: Synthesis of ferrocene-based bimetallic thiourea complexes.

with maintaining $\mathrm{pH} 4$ [24]. These tubes were incubated at human body temperature $\left(37^{\circ} \mathrm{C}\right)$ for one week. The same procedure was repeated for 3 times to get better and mean results and it was found that most significant results were obtained for concentration of $20 \mathrm{mg} / \mathrm{mL}$. After required time of incubation, the zones of inhibition were measured and the percentage of fungal inhibition was calculated and compared with the standard drug.

\section{Results and Discussion}

$1,1^{\prime}$ - $\left(4,4^{\prime}\right.$-Di-ferrocenyl)di-phenyl thiourea was synthesized by the reaction of 3-ferrocenylaniline and carbon disulfide in the presence of triethylamine as a base. Complexes 1-5 were synthesized by mixing the thiourea ligand and different metal salts in a 1:2 mole ratio (Scheme 1). Compounds Ft and 1-5 are quite stable in moist air. The molecular structures of the synthesized compounds were established on the basis of data obtained by elemental analysis and spectroscopic studies like multinuclear $\left({ }^{1} \mathrm{H}\right.$ and $\left.{ }^{13} \mathrm{C}\right) \mathrm{NMR}$ and FT-IR.

\subsection{Spectroscopic Studies}

3.1.1. NMR Spectroscopy. Representative ${ }^{1} \mathrm{H}$ NMR data for the compounds are given in the experimental section. The marker peak for $\mathbf{F t}$ is the $\mathrm{N}-\mathrm{H}$ signal that is shifted from 3.70 (3-ferrocenylaniline) to 7.99 proving the formation of the symmetrical ferrocene-based thiourea. A downfield shift in $\mathrm{N}-\mathrm{H}$ resonance was observed between $\mathrm{C}-\mathrm{N}$ bonds. The unsubstituted $\mathrm{C}_{5} \mathrm{H}_{5}$ ring of ferrocene appears as a singlet in the ${ }^{1} \mathrm{H}$ NMR spectrum at $\delta 4.10$, whereas the ortho- and metaprotons on the substituted $\mathrm{Cp}$ ring are present at $\delta 4.65$ and $\delta 4.33$, respectively, which split into three peaks on formation of the compound. One singlet for the five protons of one $\mathrm{Cp}$ ring is at $\delta 4.09 \mathrm{ppm}$ and there are two pseudo triplets at $\delta 4.33$ and $\delta 4.65 \mathrm{ppm}$ with $J$-values of $6.2 \mathrm{~Hz}$. This splitting of one peak into three peaks provides evidence for the attachment of the substituent of the one $\mathrm{Cp}$ ring of the ferrocene. For complexes 1-5, the N-H signal of the $\mathbf{F t}$ became less intense upon coordination and it is shifted downfield from the position in the free ligand. The deshielding is related to an increase of $\pi$-electron density in the $\mathrm{C}-\mathrm{N}$ bond upon coordination and it may be due to the development of hydrogen bonding between the $\mathrm{H}$ of $\mathrm{N}-\mathrm{H}$ and the $\mathrm{Cl}$ of the metal. The appearance of the $\mathrm{N}-\mathrm{H}$ signal shows that ligand is coordinated to the metals via sulfur of the Ft ligand. A small difference in chemical shift is observed in other hydrogen atoms due to $\pi$-character. All the protons in the complexes can be identified and the total number of protons estimated from the peak heights of the integration curves agrees well with the expected molecular formulae.

The ${ }^{13} \mathrm{C}$ NMR spectral data are also presented in experimental section. The $\mathrm{C}=\mathrm{S}$ peak appeared at $177.79 \mathrm{ppm}$ and all other peaks within the range confirm the synthesis of Ft. For complexes 1-5, the $\delta(\mathrm{C}=\mathrm{S})$ resonance of the ligand in the complex is shifted upfield by about $2 \mathrm{ppm}$ as compared to the free ligand. The upfield shift is attributed to the lowering of the $\delta(\mathrm{C}=\mathrm{S})$ bond strength producing a partial double bond character in the $\mathrm{C}-\mathrm{N}$ bond. The shift difference of the $\mathrm{C}=\mathrm{S}$ resonance may be related to the strength of the metal-sulfur bond. A small deshielding effect is observed for the other carbon atoms, due to an increase in the $\pi$-character of the C-N bond. 
3.1.2. Infrared Spectroscopy. Important IR data for the compounds are presented in experimental section. The characteristic bands were observed: $v(\mathrm{C}=\mathrm{S})$ at $740 \mathrm{~cm}^{-1}, v(\mathrm{~N}-\mathrm{H})$ for the secondary amine in this case at $3354 \mathrm{~cm}^{-1}, v$ (meta disubst. benzene) at $883 \mathrm{~cm}^{-1}, \nu(\mathrm{C}-\mathrm{H})$ aromatic at $3084 \mathrm{~cm}^{-1}$, $\nu(\mathrm{C}=\mathrm{C})$ aromatic at $1587 \mathrm{~cm}^{-1}$, and $\nu(\mathrm{Fe}-\mathrm{Cp})$ at $490 \mathrm{~cm}^{-1}$. These bands indicate the formation of Ft. The shift of the bands from those for the initial compound confirms the product formation. For complexes $\mathbf{1 - 5}$, characteristic bands were expected in ranges indicated: $\nu(\mathrm{C}=\mathrm{S})$ around $729-750 \mathrm{~cm}^{-1}$, $\mathrm{N}-\mathrm{H} 3204-3220 \mathrm{~cm}^{-1}$, and $\mathrm{Fc}-\mathrm{Cp}$ near $478-486 \mathrm{~cm}^{-1}$. There are low frequency shifts in the $v(\mathrm{C}=\mathrm{S})$ and $v(\mathrm{~N}-\mathrm{H})$ bands when compared to those of the free ligand.

3.2. DNA Binding Studies through Cyclic Voltammetry. Investigations of drug-DNA interactions have great importance in life science [25]. Interest in understanding the association of drug molecules with duplex DNA has been developed in the hope of understanding the mode of binding [26]. The noncovalent interactions of a drug with DNA may involve three possible modes of interaction: intercalation, groove binding, and electrostatic interactions [27]. There are different techniques which can be used to demonstrate the mode of interaction and the DNA binding parameters. One of the most sophisticated and sensitive techniques is cyclic voltammetry. Voltammetric measurements were performed in a single compartment cell with a three-electrode configuration with the objective of understanding the redox behavior and the DNA binding affinities of Ft, $\mathbf{1}$, and 4 [28-30]. The measurements were carried out with increasing concentration of calf thymus DNA ( $1 \mathrm{~mL}$ of $20 \mu \mathrm{M}, 40 \mu \mathrm{M})$ against constant concentration $(1 \mathrm{mM})$ of $\mathbf{F t}, \mathbf{1}$, and $\mathbf{4}$. The voltammogram was recorded in the absence and presence of CT-DNA in sample solutions. On addition of increasing concentration of CTDNA into a $1 \mathrm{mM}$ solution of $\mathbf{F t}, \mathbf{1}$, and $\mathbf{4}$, a drop in current $i_{\mathrm{pa}}$ and a shift in anodic potential are observed (as shown in Figures 1, 2, and 3).

The shift in peak potential is used to investigate mode of interaction between Ft, $\mathbf{1}$, and $\mathbf{4}$ and DNA. The slightly positive shift in the peak potential is indicative intercalation of the compounds into double helical structure of DNA. The binding ratio of reduced and oxidized species is calculated according to the following equation $[19,31]$ :

$$
\mathrm{Eb}^{\circ}-\mathrm{Ef}^{\circ}=0.05916 \log \left(\frac{K_{\text {red. }}}{K_{\text {oxd. }}}\right) \text {, }
$$

where $\mathrm{Eb}^{\circ}$ and $\mathrm{Ef}^{\circ}$ are the formal potentials of the free and bound forms of drug, respectively. The positive shift indicates intercalation with DNA for $\mathbf{F t}, \mathbf{1}$, and $\mathbf{4}$. The drop in current is attributed to diffusion of the drug into the double helical DNA resulting in the formation of a supramolecular complex. As the supramolecular complex is formed, the number of electrons transferred is decreased and hence the drop off in current. The increase in molecular weight of the compound (due to adduct formation with DNA) also justifies the idea that heavy molecules migrate slowly to the electrode and so

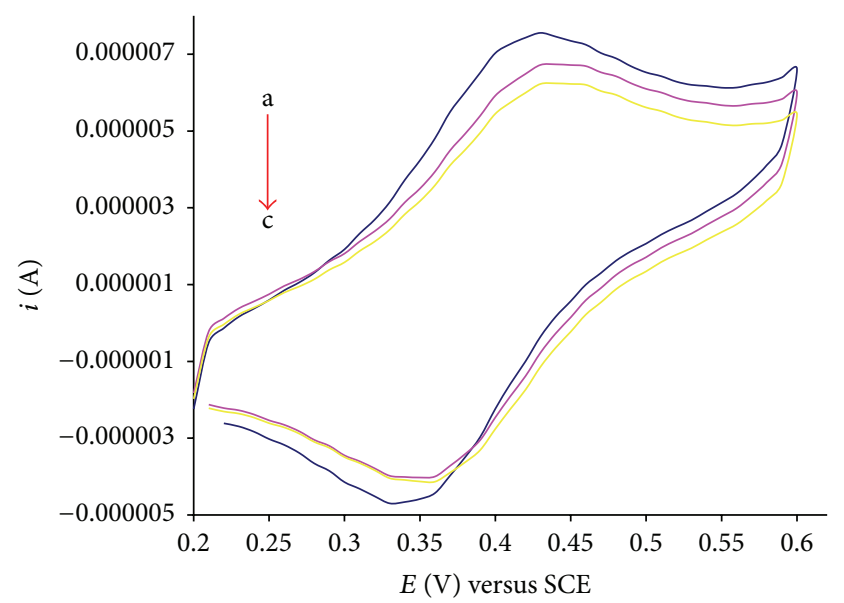

FIgURE 1: Cyclic voltammograms of $1 \mathrm{mM}$ compound Ft recorded at $100 \mathrm{mV} / \mathrm{s}$ potential sweep rate on glassy carbon electrode at $25^{\circ} \mathrm{C}$ in the absence (a) and presence of $1 \mathrm{~mL}$ of $20 \mu \mathrm{M}, 40 \mu \mathrm{M}$ with increasing concentration of CT-DNA (b-c) in 20\% aqueous DMSO buffer at $\mathrm{pH}$ 7.0; supporting electrolyte $0.1 \mathrm{M} \mathrm{KCl}$.

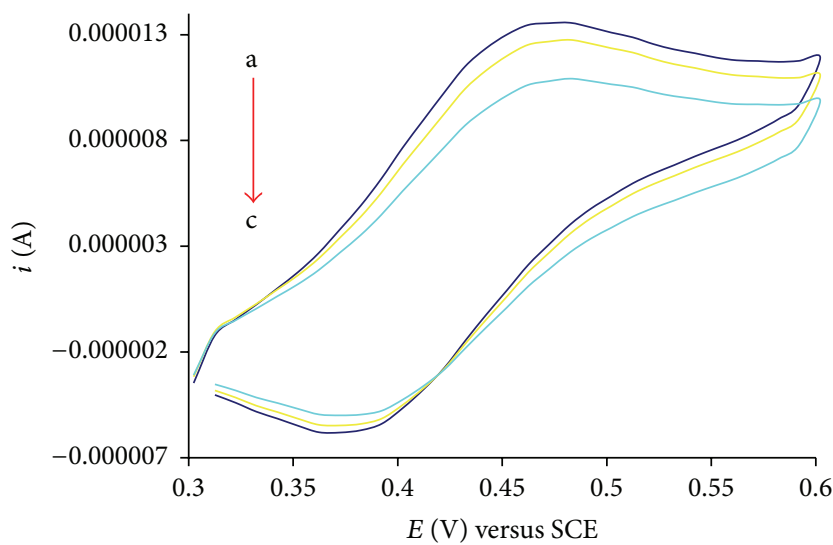

FIGURE 2: Cyclic voltammograms of $1 \mathrm{mM}$ compound 1 recorded at $100 \mathrm{mV} / \mathrm{s}$ potential sweep rate on glassy carbon electrode at $25^{\circ} \mathrm{C}$ in the absence (a) and presence of $1 \mathrm{~mL}$ of $20 \mu \mathrm{M}, 40 \mu \mathrm{M}$ with increasing concentration of CT-DNA (b-c) in 20\% aqueous DMSO buffer at $\mathrm{pH} 7.0$; supporting electrolyte $0.1 \mathrm{M} \mathrm{KCl}$.

a decrease in current is observed. The binding constant is determined using the following equation [32]:

$$
\frac{1}{[\mathrm{DNA}]}=\frac{K(1-A)}{1-\left(i / i_{0}\right)}-K,
$$

where $K$ is the binding constant, $i$ and $i_{o}$ are the peak currents with and without CT-DNA, and $A$ is the proportionality constant. The plot of $1 /[\mathrm{DNA}]$ versus $1 /\left(1-i / i_{0}\right)$ yields binding constants and is listed in Table 1 .

The DNA binding affinity of 3-ferrocenylaniline has already been reported by our research group [17]. The DNA binding affinity of 3 -ferrocenylaniline is greater than that of Ft, 1, or 4 . This difference may be attributed to the mixture of binding modes; that is, the ferrocenyl moiety binds electrostatically to the negatively charged phosphate of the DNA 


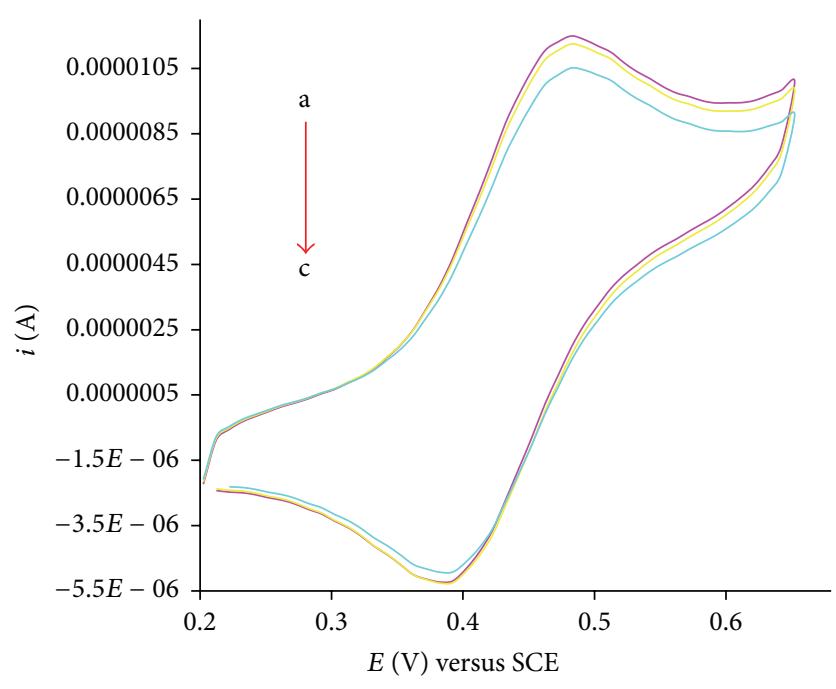

FIGURE 3: Cyclic voltammograms of $1 \mathrm{mM}$ compound 4 recorded at $100 \mathrm{mV} / \mathrm{s}$ potential sweep rate on glassy carbon electrode at $25^{\circ} \mathrm{C}$ in the absence (a) and presence of $1 \mathrm{~mL}$ of $20 \mu \mathrm{M}, 40 \mu \mathrm{M}$ with increasing concentration of CT-DNA (b-c) in $20 \%$ aqueous DMSO buffer at $\mathrm{pH} 7.0$; supporting electrolyte $0.1 \mathrm{M} \mathrm{KCl}$.

TABLE 1: Binding constant and binding energy values of 1-4 and 3ferrocenylaniline [17].

\begin{tabular}{lcc}
\hline Compound & Binding constant $\left(\mathrm{M}^{-1}\right)$ & $-\Delta G(\mathrm{~kJ} / \mathrm{mol})$ \\
\hline $\mathbf{F t}$ & $3.43 \times 10^{3}$ & 19.41 \\
$\mathbf{1}$ & $4.63 \times 10^{3}$ & 20.23 \\
$\mathbf{2}$ & $4.83 \times 10^{3}$ & 20.41 \\
$\mathbf{3}$ & $4.57 \times 10^{3}$ & 20.35 \\
$\mathbf{4}$ & $5.85 \times 10^{3}$ & 20.87 \\
3-Ferrocenylaniline & $9.39 \times 10^{3}$ & 21.67 \\
\hline
\end{tabular}

backbone and there is intercalation of the planar phenyl moiety into the base pair pockets. The binding constants of 1-4 and 3-ferrocenylaniline are listed in Table 1.

The free binding energy is calculated from the equation $-\Delta G=\mathrm{RT} \ln K$. The negative value of free binding energy of 1-4 and 3-ferrocenylaniline in $\mathrm{kJ} / \mathrm{mol}$ at $25^{\circ} \mathrm{C}$ shows the spontaneity of compound-DNA interaction [17], as listed in Table 1, while compound $\mathbf{5}$ showed almost same behavior as compound 3 .

3.3. DNA Binding Studies through Viscometry. Another useful technique to prove intercalation is the viscosity measurement, which is sensitive to the length change of DNA due to the lengthening of DNA helix as the base pair pockets are widened to accommodate the binding molecule. This technique is regarded as the least ambiguous and the most critical test of the binding mode in solution under appropriate conditions (constant temperature at $25.0 \pm 0.1^{\circ} \mathrm{C}$ in a thermostatic bath). The plots reveal negative changes in $\left(\eta / \eta_{0}\right)$ with increasing concentration of all compounds. The graph between relative specific viscosity $\left(\eta / \eta_{0}\right)$ and [compound]/[DNA] for $\mathbf{1}$ and $\mathbf{5}$ is shown as representation in Figures 4 and 5. This mode of action is suggestive of

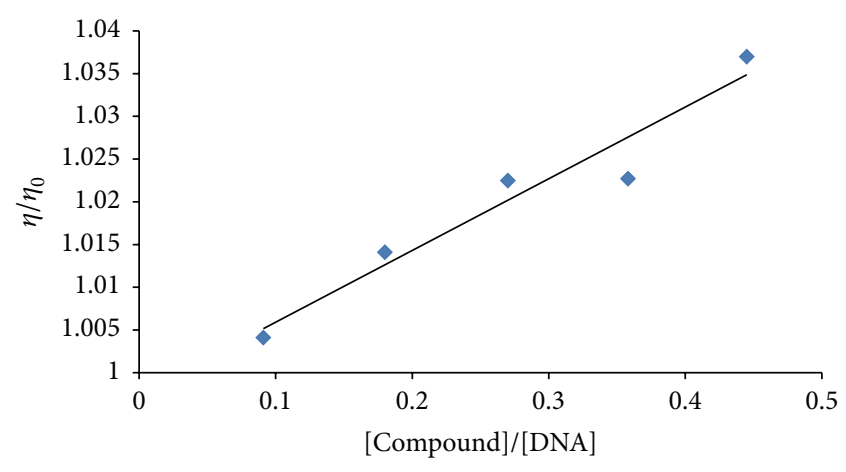

FIGURE 4: Effect of increasing concentration of compound 1 on the relative viscosity of DNA at $25^{\circ} \mathrm{C}$. [DNA] $=30 \mu \mathrm{M}$ and [compound$1]=5-25 \mu \mathrm{M}$.

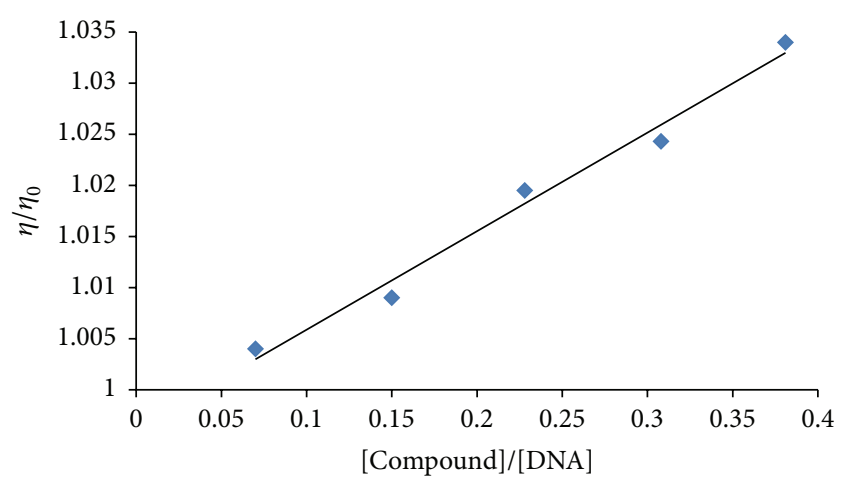

FIGURE 5: Effect of increasing concentration of compound 5 on the relative viscosity of DNA at $25^{\circ} \mathrm{C}$. [DNA] $=30 \mu \mathrm{M}$ and [compound5] $=5-25 \mu \mathrm{M}$.

intercalation that may cause lengthening of the DNA chain [33].

3.4. In Vitro Inhibition Studies of Alkaline Phosphatase. The effect of various concentrations of compounds $\mathbf{F t}$ and 1-5 $(10 \mu \mathrm{L}, 20 \mu \mathrm{L}, 40 \mu \mathrm{L}$, and $60 \mu \mathrm{L})$ on the activity of the enzyme, alkaline phosphatase EC 3.1.3.1, was studied for the hydrolysis of p-nitrophenyl phosphate (pNPP). Alkaline phosphatase catalyzes the transfer of phosphate groups to water (hydrolysis) or alcohol (transphosphorylation) using a wide variety of phosphomonoesters and is characterized by high $\mathrm{pH}$ optima and a broad substrate specificity [34]. Here, we have practical evidence that the presence of different metals resulted in the deactivation of the enzyme of $40 \mu \mathrm{L}$ as concentration. The activity of enzyme was markedly decreased by increasing the concentration of the compounds. The \% activity of the enzyme (alkaline phosphatase) is presented in Figure 6.

3.5. Antibacterial Activity. In vitro evaluation of antibacterial activity was successfully carried out. The experiments were repeated three times and the results are reported as means of at least three determinations and the results are summarized in Table 2. As evident from Table 2, Ft and 1-5 exhibited 
TABle 2: Antibacterial activity of Ft and 1-5.

\begin{tabular}{|c|c|c|c|c|c|c|c|c|}
\hline \multirow[t]{2}{*}{ Chemical codes } & \multicolumn{2}{|c|}{$\begin{array}{l}\text { Staphylococcus aureus } \\
\text { (2) }(G+\mathrm{ve})\end{array}$} & \multicolumn{2}{|c|}{$\begin{array}{l}\text { Klebsiella pneumoniae } \\
\text { (1) }(G-\mathrm{ve})\end{array}$} & \multicolumn{2}{|c|}{$\begin{array}{l}\text { Micrococcus luteus } \\
\text { (2) }(G+\mathrm{ve})\end{array}$} & \multicolumn{2}{|c|}{$\begin{array}{l}\text { Escherichia coli } \\
\text { (1) }(G-\mathrm{ve})\end{array}$} \\
\hline & Radius (mm) & $\%$ value & Radius (mm) & $\%$ value & Radius (mm) & $\%$ value & Radius (mm) & $\%$ value \\
\hline Imipenem & 18 & 100 & 20 & 100 & 18 & 100 & 20 & 100 \\
\hline $\mathrm{Ft}$ & 13 & 72 & 02 & 11 & 16 & 89 & 02 & 11 \\
\hline 1 & 00 & 00 & 3 & 17 & 3 & 17 & 5 & 28 \\
\hline 2 & 3 & 17 & 2 & 11 & 4 & 22 & 3 & 17 \\
\hline 3 & 7 & 39 & 3 & 17 & 00 & 00 & 4 & 22 \\
\hline 4 & 9 & 50 & 6 & 33 & 7 & 39 & 11 & 61 \\
\hline 5 & 3 & 17 & 04 & 20 & 00 & 00 & 03 & 17 \\
\hline
\end{tabular}

TABle 3: Antifungal activity of Ft and 1-5.

\begin{tabular}{|c|c|c|c|c|c|}
\hline Compound codes & $\begin{array}{l}\text { Concentration } \\
(\mathrm{mg} / 100 \mathrm{~mL})\end{array}$ & $\begin{array}{l}\text { Negative control } \\
\text { growth/DMSO }(\mathrm{cm})\end{array}$ & $\begin{array}{l}\text { Culture length (in } \\
\text { control) }(\mathrm{cm})\end{array}$ & $\begin{array}{c}\text { Fungal growth length (in } \\
\text { sample) }\end{array}$ & $\begin{array}{l}\% \text { inhibition of fungal } \\
\text { growth }\end{array}$ \\
\hline \multirow{3}{*}{$\mathbf{F t}$} & 3.00 & 10.40 & 11.00 & 7.10 & 35.50 \\
\hline & 5.00 & 10.00 & 11.00 & 5.60 & 49.00 \\
\hline & 20.00 & 10.00 & 11.00 & 3.30 & 70.00 \\
\hline \multirow{3}{*}{1} & 3.00 & 9.80 & 10.50 & 9.70 & 7.60 \\
\hline & 5.00 & 9.50 & 10.50 & 8.60 & 18.00 \\
\hline & 20.00 & 10.00 & 10.50 & 7.00 & 33.30 \\
\hline \multirow{3}{*}{2} & 3.00 & 10.20 & 11.50 & 10.20 & 11.30 \\
\hline & 5.00 & 10.30 & 11.50 & 9.50 & 17.40 \\
\hline & 20.00 & 10.00 & 11.50 & 8.10 & 29.56 \\
\hline \multirow{3}{*}{3} & 3.00 & 11.00 & 12.00 & 10.50 & 12.50 \\
\hline & 5.00 & 11.50 & 12.00 & 8.20 & 31.66 \\
\hline & 20.00 & 11.60 & 12.00 & 6.30 & 47.50 \\
\hline \multirow{2}{*}{4} & 3.00 & 10.70 & 10.50 & 7.30 & 30.48 \\
\hline & 5.00 & 10.40 & 10.50 & 4.50 & 57.14 \\
\hline \multirow{3}{*}{5} & 3.00 & 9.60 & 10.00 & 8.40 & 16.00 \\
\hline & 5.00 & 9.00 & 10.00 & 6.30 & 37.00 \\
\hline & 20.00 & 9.50 & 10.00 & 2.80 & 72.00 \\
\hline
\end{tabular}

Std. drugs = Terbinafine (100\%).

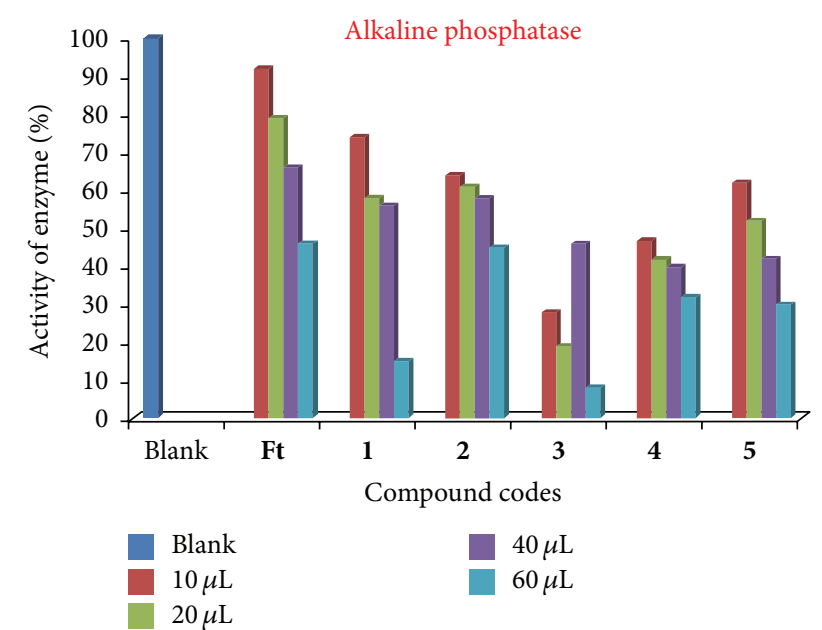

FIGURE 6: Enzymatic studies (alkaline phosphatase) of compounds Ft and 1-5. significant inhibitory activity against the two strains, Staphylococcus aureus and Micrococcus luteus, as compared to standard drug (imipenem) at the tested concentration.

3.6. Antifungal Activity. Table 3 summarizes the antifungal activity of the compounds against pathogenic yeast species. The results reveal that all the compounds had promising antifungal activities against Aspergillus niger and poor activities against other yeasts. These results suggest that the compound has effective activities against selective yeasts. Iron is essential for microorganisms as a trace nutrient. Moreover, several studies had reported that iron containing organometallic compounds showed good antimicrobial activities [35].

\section{Conclusion}

Ferrocene incorporated bimetallics (1-5) have been synthesized and successfully characterized. During DNA binding 
studies, the shift in formal potential reveals the mode of interaction between the complexes and DNA. Compounds Ft, $\mathbf{1}$, and $\mathbf{4}$ undergo intercalation into the double helix structure of DNA and this result is also supported by viscometric measurements. These complexes have been checked for their alkaline phosphatase activity in the presence and absence of inhibitor which shows that by the addition of inhibitor the activity of enzyme decreases and at higher concentration it is completely inhibited. Compounds Ft and 1-5 are biologically active against Gram-positive bacteria ( $S$. aureus and $M$. luteus), Gram-negative bacteria (E. coli and K. pneumoniae), and selective yeast $A$. niger.

\section{Conflict of Interests}

The authors declare that there is no conflict of interests.

\section{Acknowledgments}

Shafqat Ali acknowledges the Department of Microbiology, Quaid-i-Azam University, Pakistan, and Department of Chemistry, McGill University, Montreal, QC, Canada, for their support.

\section{References}

[1] D. Savage, N. Neary, G. Malone, S. R. Alley, J. F. Gallagher, and P. T. M. Kenny, "The synthesis and structural characterization of novel $N$-meta-ferrocenyl benzoyl amino acid esters," Inorganic Chemistry Communications, vol. 8, no. 5, pp. 429-432, 2005.

[2] Ž. Petrovski, M. R. P. Norton de Matos, S. S. Braga et al., "Synthesis, characterization and antitumor activity of 1,2-disubstituted ferrocenes and cyclodextrin inclusion complexes," Journal of Organometallic Chemistry, vol. 693, no. 4, pp. 675-684, 2008.

[3] H. Parveen, F. Hayat, A. Salahuddin, and A. Azam, "Synthesis, characterization and biological evaluation of novel 6-ferrocenyl-4-aryl-2-substituted pyrimidine derivatives," European Journal of Medicinal Chemistry, vol. 45, no. 8, pp. 3497-3503, 2010.

[4] R. H. Fish and G. Jaouen, "Bioorganometallic chemistry: structural diversity of organometallic complexes with bioligands and molecular recognition studies of several supramolecular hosts with biomolecules, alkali-metal ions, and organometallic pharmaceuticals," Organometallics, vol. 22, no. 11, pp. 2166-2177, 2003.

[5] D. Savage, G. Malone, J. F. Gallagher, Y. Ida, and P. T. M. Kenny, "Synthesis and structural characterization of $N$-paraferrocenyl benzoyl amino acid ethyl esters and the X-ray crystal structures of the glycyl and ( \pm )-2-aminobutyric acid derivative Fc $\mathrm{C}_{6} \mathrm{H}_{4} \mathrm{CONHCH}\left(\mathrm{C}_{2} \mathrm{H}_{5}\right) \mathrm{CO}_{2}$ Et," Journal of Organometallic Chemistry, vol. 690, no. 2, pp. 383-393, 2005.

[6] Á. Mooney, A. J. Corry, D. O’Sullivan, D. K. Rai, and P. T. M. Kenny, "The synthesis, structural characterization and in vitro anti-cancer activity of novel $\mathrm{N}$-(3-ferrocenyl-2-naphthoyl) dipeptide ethyl esters and novel N-(6-ferrocenyl-2-naphthoyl) dipeptide ethyl esters," Journal of Organometallic Chemistry, vol. 694, no. 6, pp. 886-894, 2009.

[7] A. J. Corry, A. Goel, S. R. Alley et al., "N-ortho-ferrocenyl benzoyl dipeptide esters: synthesis, structural characterization and in vitro anti-cancer activity of $\mathrm{N}$-ortho-(ferrocenyl)benzoylglycine-L-alanine ethyl ester and $\mathrm{N}$-ortho-(ferrocenyl)benzoylL-alanine-glycine ethyl ester," Journal of Organometallic Chemistry, vol. 692, no. 6, pp. 1405-1410, 2007.

[8] M. F. R. Fouda, M. M. Abd-Elzaher, R. A. Abdelsamaia, and A. A. Labib, "On the medicinal chemistry of ferrocene," Applied Organometallic Chemistry, vol. 21, no. 8, pp. 613-625, 2007.

[9] Y.-F. Yuan, L.-Y. Zhang, J.-P. Cheng, and J.-T. Wang, "Electrochemical behaviour of ferrocenyl-containing acyl thiourea derivatives," Transition Metal Chemistry, vol. 22, no. 3, pp. 281283, 1997.

[10] J.-Z. Liu, B.-A. Song, H.-T. Fan et al., "Synthesis and in vitro study of pseudo-peptide thioureas containing $\alpha$-aminophosphonate moiety as potential antitumor agents," European Journal of Medicinal Chemistry, vol. 45, no. 11, pp. 5108-5112, 2010.

[11] Z. Zhong, R. Xing, S. Liu, L. Wang, S. Cai, and P. Li, “Synthesis of acyl thiourea derivatives of chitosan and their antimicrobial activities in vitro," Carbohydrate Research, vol. 343, no. 3, pp. 566-570, 2008.

[12] N. Khan, B. Lal, A. Badshah et al., "DNA binding studies of new ferrocene based bimetallics," Journal of the Chemical Society of Pakistan, vol. 35, no. 3, pp. 916-921, 2013.

[13] S. Hussain, A. Badshah, B. Lal et al., "New supramolecular ferrocene incorporated $\mathrm{N}, \mathrm{N}^{\prime}$-disubstituted thioureas: synthesis, characterization, DNA binding, and antioxidant studies," Journal of Coordination Chemistry, vol. 67, no. 12, pp. 2148-2159, 2014.

[14] V. G. Vaidyanathan and B. U. Nair, "Synthesis, characterization and binding studies of chromium(III) complex containing an intercalating ligand with DNA," Journal of Inorganic Biochemistry, vol. 95, no. 4, pp. 334-342, 2003.

[15] S. Ali, A. A. Altaf, A. Badshah et al., "DNA interaction, Antibacterial and Antifungal studies of 3-nitrophenylferrocene," Journal of the Chemical Society of Pakistan, vol. 35, no. 3, pp. 922928, 2013.

[16] X.-B. Chen, Q. Ye, Q. Wu, Y.-M. Song, R.-G. Xiong, and X.Z. You, "The first organometallic carbonyl tungsten complex of antibacterial drug norfloxacin," Inorganic Chemistry Communications, vol. 7, no. 12, pp. 1302-1305, 2004.

[17] S. Ali, A. Badshah, A. A. Ataf, Imtiaz-ud-Din, B. Lal, and K. M. Khan, "Synthesis of 3-ferrocenylaniline: DNA interaction, antibacterial, and antifungal activity," Medicinal Chemistry Research, vol. 22, no. 7, pp. 3154-3159, 2013.

[18] D. B. G. Williams and M. Lawton, "Drying of organic solvents: quantitative evaluation of the efficiency of several desiccants," Journal of Organic Chemistry, vol. 75, no. 24, pp. 8351-8354, 2010.

[19] C.-L. Bian, Q.-X. Zeng, L.-J. Yang, H.-Y. Xiong, X.-H. Zhang, and S.-F. Wang, "Voltammetric studies of the interaction of rutin with DNA and its analytical applications on the MWNTs$\mathrm{COOH} / \mathrm{Fe}_{3} \mathrm{O}_{4}$ modified electrode," Sensors and Actuators B: Chemical, vol. 156, no. 2, pp. 615-620, 2011.

[20] A. Shah, M. Zaheer, R. Qureshi, Z. Akhter, and M. Faizan Nazar, "Voltammetric and spectroscopic investigations of 4nitrophenylferrocene interacting with DNA," Spectrochimica Acta Part A: Molecular and Biomolecular Spectroscopy, vol. 75, no. 3, pp. 1082-1087, 2010.

[21] M. Sönmez, İ. Berber, and E. Akbaş, "Synthesis, antibacterial and antifungal activity of some new pyridazinone metal complexes," European Journal of Medicinal Chemistry, vol. 41, no. 1, pp. 101-105, 2006. 
[22] A. Saeed, U. Shaheen, A. Hameed, and S. Z. H. Naqvi, "Synthesis, characterization and antimicrobial activity of some new 1(fluorobenzoyl)-3-(fluorophenyl)thioureas," Journal of Fluorine Chemistry, vol. 130, no. 11, pp. 1028-1034, 2009.

[23] F. Shaheen, A. Badshah, M. Gielen et al., "In vitro assessment of cytotoxicity, anti-inflammatory, antifungal properties and crystal structures of metallacyclic palladium(II) complexes," Journal of Organometallic Chemistry, vol. 695, no. 3, pp. 315-322, 2010.

[24] M. Nath, Sulaxna, X. Song, G. Eng, and A. Kumar, "Synthesis and spectral studies of organotin(IV) 4-amino-3-alkyl1,2,4-triazole-5-thionates: in vitro antimicrobial activity," Spectrochimica Acta-Part A: Molecular and Biomolecular Spectroscopy, vol. 70, no. 4, pp. 766-774, 2008.

[25] H. Ilkhani, M. R. Ganjali, M. Arvand, and P. Norouzi, "Electrochemical and spectroscopic study of samarium ion interaction with DNA in different pHs," International Journal of Electrochemical Science, vol. 5, no. 2, pp. 168-176, 2010.

[26] Y.-J. Liu and C.-H. Zeng, "Synthesis and DNA interaction studies of ruthenium(II) complexes with isatino[1, 2-b]-1,4,8,9tetraazatriphenylene as an intercalative ligand," Transition Metal Chemistry, vol. 34, no. 4, pp. 455-462, 2009.

[27] B. S. P. Reddy, S. M. Sondhi, and J. W. Lown, "Synthetic DNA minor groove-binding drugs," Pharmacology \& Therapeutics, vol. 84, no. 1, pp. 1-111, 1999.

[28] A. Shah, A. M. Khan, R. Qureshi, F. L. Ansari, M. F. Nazar, and S. S. Shah, "Redox behavior of anticancer chalcone on a glassy carbon electrode and evaluation of its interaction parameters with DNA," International Journal of Molecular Sciences, vol. 9, no. 8, pp. 1424-1434, 2008.

[29] S. Shujha, A. Shah, Zia-ur-Rehman et al., "Diorganotin(IV) derivatives of ONO tridentate Schiff base: synthesis, crystal structure, in vitro antimicrobial, anti-leishmanial and DNA binding studies," European Journal of Medicinal Chemistry, vol. 45, no. 7, pp. 2902-2911, 2010.

[30] Zia-ur-Rehman, A. Shah, N. Muhammad, S. Ali, R. Qureshi, and I. S. Butler, "Synthesis, characterization and DNA binding studies of penta- and hexa-coordinated diorganotin(IV) 4-(4nitrophenyl)piperazine-1-carbodithioates," Journal of Organometallic Chemistry, vol. 694, no. 13, pp. 1998-2004, 2009.

[31] M. S. Ibrahim, "Voltammetric studies of the interaction of nogalamycin antitumor drug with DNA," Analytica Chimica Acta, vol. 443, no. 1, pp. 63-72, 2001.

[32] N. Raman, K. Pothiraj, and T. Baskaran, "DNA interaction, antimicrobial, electrochemical and spectroscopic studies of metal(II) complexes with tridentate heterocyclic Schiff base derived from $2^{\prime}$-methylacetoacetanilide," Journal of Molecular Structure, vol. 1000, no. 1-3, pp. 135-144, 2011.

[33] M. S. Ibrahim, I. S. Shehatta, and A. A. Al-Nayeli, "Voltammetric studies of the interaction of lumazine with cyclodextrins and DNA," Journal of Pharmaceutical and Biomedical Analysis, vol. 28, no. 2, pp. 217-225, 2002.

[34] J. G. Zalatan, T. D. Fenn, and D. Herschlag, "Comparative enzymology in the alkaline phosphatase superfamily to determine the catalytic role of an active-site metal ion," Journal of Molecular Biology, vol. 384, no. 5, pp. 1174-1189, 2008.

[35] A. Imtiaz-ud-Din, M. Mazhar, K. M. Khan, M. F. Mahon, and K. C. Molloy, "Studies of bimetallic carboxylates: their synthesis, characterization, biological activity and X-ray structure," Journal of Organometallic Chemistry, vol. 689, no. 5, pp. 899-908, 2004. 

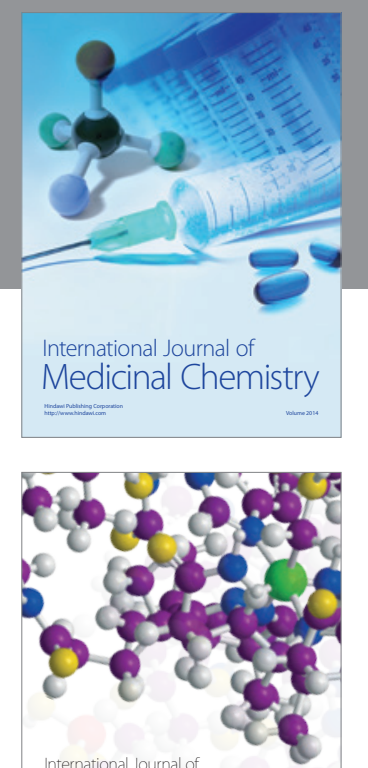

\section{Carbohydrate} Chemistry

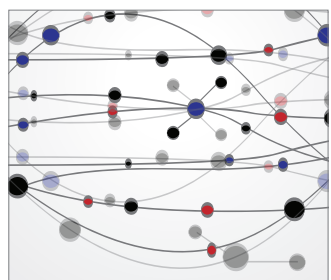

The Scientific World Journal
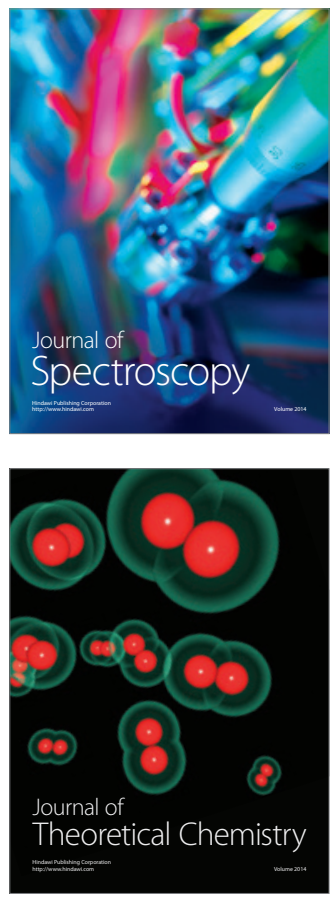
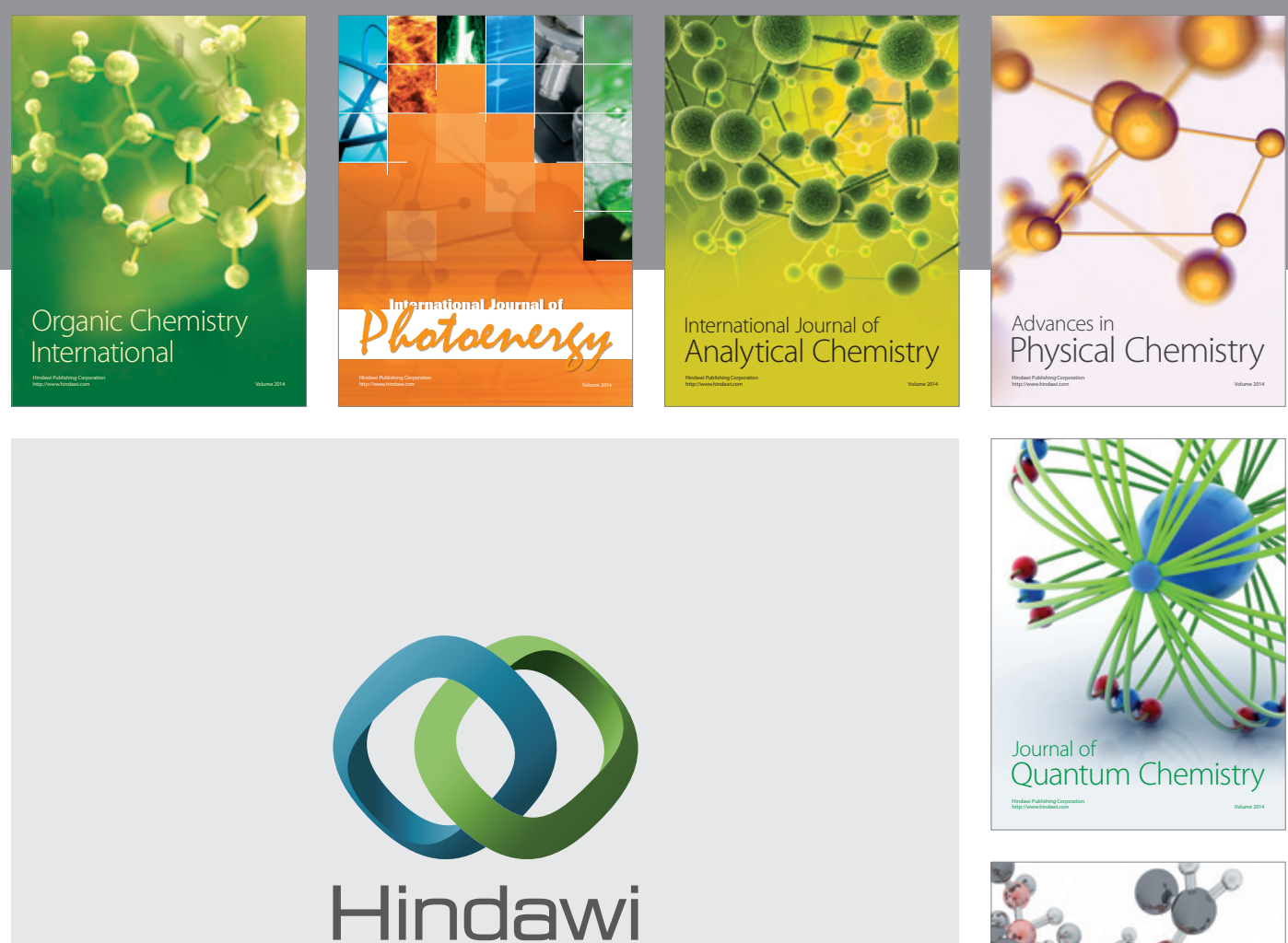

Submit your manuscripts at

http://www.hindawi.com

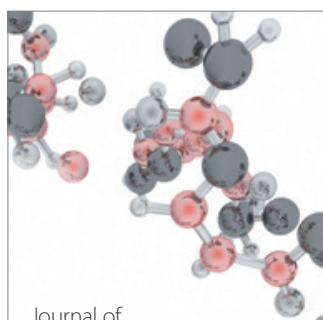

Analytical Methods

in Chemistry

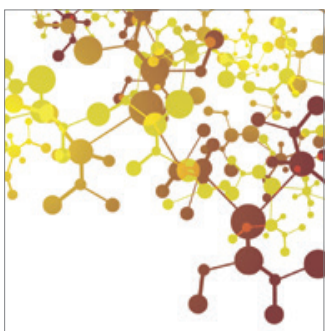

Journal of

Applied Chemistry

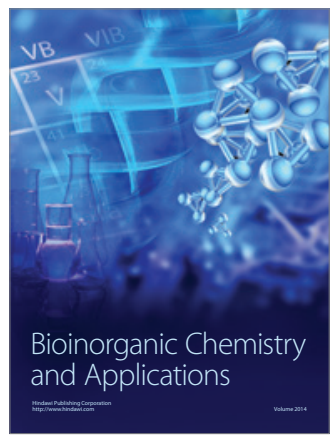

Inorganic Chemistry
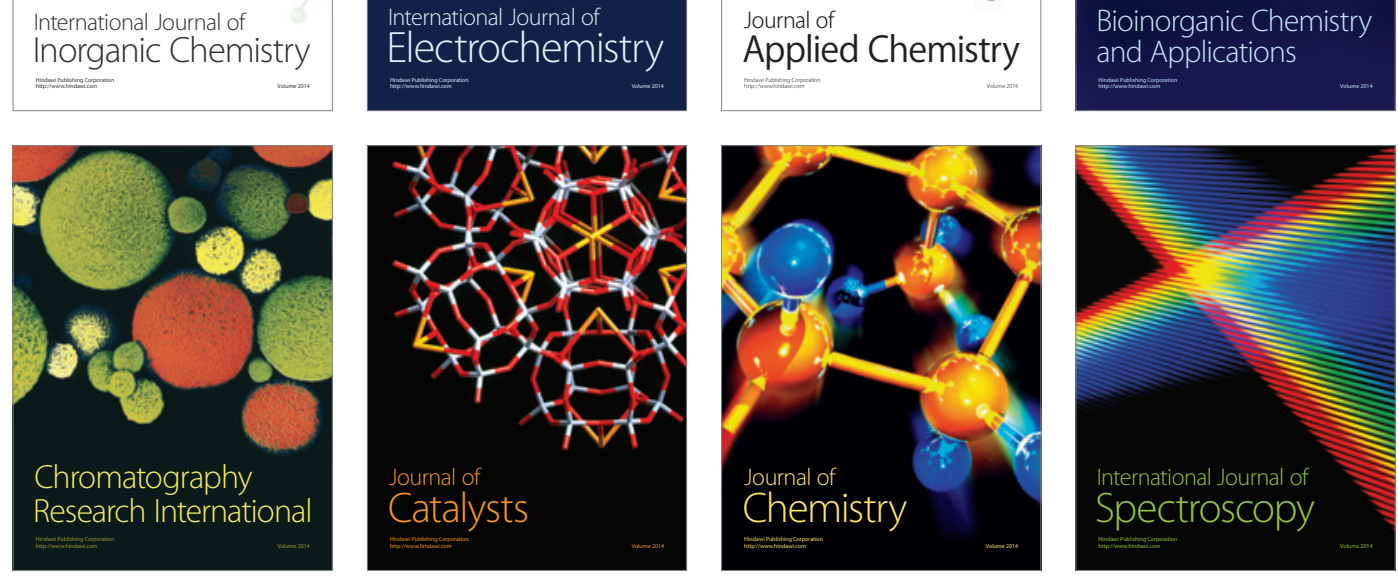